International Research Journal of Management, IT \& Social Sciences
Available online at https://sloap.org/journals/index.php/irjmis/
Vol. 7 No. 3, May 2020, pages: 38-49
ISSN: 2395-7492
https://doi.org/10.21744/irjmis.v7n3.887

\title{
The Role of Purchase Intention in Mediating The Effect of Perceived Price and Perceived Quality on Purchase Decision
}

Article history:

Submitted: 27 January 2020

Revised: 09 February 2020

Accepted: 18 March 2020

\section{Keywords:}

perceived price; perceived quality;

purchase Decision;

purchase intention;

smartphone;

\begin{abstract}
The study was aimed to explain the role of purchase intention in mediating perceived price and perceived quality of purchase decisions of Xiaomi Smartphone customers in Denpasar City. The sample is taken by a purposive sampling method as much as 130 Xiaomi customers in Denpasar. The Partial Least Square (PLS) analysis technique was applied. The result found that both perceived price and perceived quality positively and significantly affect purchase intentions and purchase decisions of Xiaomi smartphones. Furthermore, the role of purchase intention also significantly mediated the perceived price and perceived quality towards the Xiaomi smartphone purchase decision. This implies that the company should convince that the Xiaomi smartphone is worth the price, continue to improve the latest features to be more powerful and increasing the number of Xiaomi service centers in Indonesia, especially in the city of Denpasar.
\end{abstract}

International research journal of management, IT and social sciences (C) 2020. This is an open access article under the CC BY-NC-ND license (https://creativecommons.org/licenses/by-nc-nd/4.0/).

Corresponding author:

Kadek Aria Satriawan,

Faculty of Economics and Business, Udayana University, Denpasar, Indonesia

Email address: aria.satriawan@yahoo.co.id

Udayana University, Denpasar, Indonesia

Udayana University, Denpasar, Indonesia 


\section{Introduction}

Smartphone usage in Indonesia reaches 92 million units in 2019. This increased from the previous year which was 83.5 million units (Databoks, 2019). Hidayah (2016), states the purchase intention is in person urge to buy goods or services by measuring attitudes toward the class of product or brand. Various marketing strategies are launched by companies to obtain and maintain their markets including differentiation. Differentiation has been realized in the form of product prices and innovations offered to consumers (Mahajaya Utama \& Sudiksa, 2017).

Based on the International Data Corporation (IDC) Quarterly Mobile Phone Tracker survey taken from Kompas.com, Xiaomi as one of the smartphones that shifted Samsung's growth as the market leader in Indonesia throughout 2018. Xiaomi's sales in 2018 reached 8 million units, up by 2 million units from the previous year, it made Xiaomi experience growth of 139.4 percent year on year growth. While Samsung's growth in 2018 was under Xiaomi, which was 21.5 percent.

Various types of smartphone products offered to the market, providing many choices for consumers. Smartphone manufacturers are currently competing to offer mobile phones with sophisticated features but at relatively low prices. One of the factors that consumers consider in making a purchase decision is the price and quality, the quality factor consists of product performance and product specifications which are seen from the comparison of prices and quality (Babin et al., 2003; Wichman, 2014).

Octaviona (2016), found that perceived price did not have a positive and significant effect on purchasing decisions. Different results were obtained by Hastuti et al. (2018), which states that perceived price has a positive and significant influence on the decision to buy an Oppo smartphone. Furthermore, Putri (2018), stated that an intention will be formed if the price is in line with expectation. The higher intention will encourage consumers to make purchase decisions.

Research on the effect of perceived quality on purchasing decisions has also been conducted by Rawung et al. (2015), who found that perceived quality does not have a positive and significant effect on purchasing decisions. However, different results were obtained by Hendra (2017), who found that perceived quality has a positive and significant influence on purchasing decisions. Adriansyah et al. (2013), stated that the quality of the product is an antecedent that affects the purchase intention, the higher the quality of a product, the higher the purchase intention of the product. High consumer purchase intentions will encourage consumers to buy a product (Jang \& Namkung, 2009; González et al., 2007).

\section{Literature review}

\section{Effect of perceived price on purchase intention}

Price is the amount of value exchanged by consumers for the benefit of owning or using an exchange service product (Widyastuti \& Said, 2017). Product prices are divided into three dimensions: fair prices, fixed prices, and relative prices (Safitri, 2018). Price is considered important to influence consumer perception (Kayacan, 2017). Li (2017), conducted research found that perceived price had a positive and significant effect on purchase intentions at the Taichung International Travel Fair Taiwan. Chao (2016), in his research, examines the impact of brand image and discounted prices on purchase intentions with consumer attitudes as mediators. The results of his research indicate that prices have a positive and significant effect on purchase intentions. Wang \& Cheng (2016), conducted a study in Taiwan that indicates that perceived price has a positive and significant effect on purchase intentions.

H1: The perceived price has a positive and significant effect on buying intentions

\section{Effect of perceived quality on purchase intention}

The quality of a product is a consumer assessment of product superiority or level of excellence (Alfred, 2013). A company must be able to make many strategies to master market position and improve the quality of its products (Brata et al., 2017). Tansil \& Tielung (2014), researched the SHMILY Cupcake shop in Manado showed that perceived quality had a positive and significant effect on the purchase intention. Gama et al., (2018), found that perceived quality had a positive and significant effect on purchase intention, in line with Saleem et al. (2015), and Lomboan (2017), that also shows the positive and significant effect of perceived quality on purchase intention.

H2: Perceived quality has a positive and significant effect on purchase intentions

Satriawan, K. A., \& Setiawan, P. Y. (2020). The role of purchase intention in mediating the effect of perceived price and perceived quality on purchase decision. International Research Journal of Management,

IT and Social Sciences, 7(3), 38-49. https://doi.org/10.21744/irjmis.v7n3.887 


\section{Effect of perceived price on purchase decision}

Hustic \& Gregurec (2015), in their research on the effect of perceived price on consumer purchasing decisions, found that price is a factor that has a positive and significant effect on purchasing decisions. Hastuti et al. (2018), examined the effect of brand image and perceived price on purchase decisions. The results found that the perceived price had a positive and significant impact on the decision to buy an Oppo smartphone in Kendari.

H3: The perceived price has a positive and significant effect on purchase decisions

\section{Effect of perceived quality on purchase decision}

Rawung et al. (2015), examined the analysis of product quality, brand, and price on purchasing decisions of Suzuki Motor at PT. Sinar Galesong Pratama Manado. The results found that quality does not significantly influence purchasing decisions. Research conducted by Hendra (2017), found different results, that perceived quality had a positive and significant effect on purchasing decisions. The results of research conducted by Hoseinian \& Asadollahi (2017), also show that perceived quality has a positive and significant effect on purchasing decisions.

H4: Perceived quality has a positive and significant effect on purchase decisions

\section{Effect of perceived quality on purchase decision}

Septifani et al. (2014), found that purchase intention had a significant and positive effect on purchasing decisions. Putra et al. (2016), also found the same result. Purchase intention can produce a buying decision. The intention of consumers to a product will result in a consumer decision to determine further choices of the products of interest (Lee \& Shin, 2010; Balakrishnan et al., 2014; Akhter, 2003; Bian \& Forsythe, 2012). Waspodo (2010), in his research, found that purchase intention has a positive and significant effect on purchasing decisions of Honda Vario in Semarang City.

H5: Purchase intention has a positive and significant effect on purchase decisions

\section{The role of purchase intention in mediates perceived price on purchase decision}

Price is one of the important variables in marketing where the price can influence consumers in making decisions to buy a product (Anwar, 2017; Zhang \& Zhang, 2007; O’Cass, 2000; Stock \& Zinszer, 1987). Purchase intention is influenced by the value of the product being evaluated, if the perceived benefits outweigh the sacrifice to obtain it, then the drive to buy it is higher (Septiana, 2018). Purchase decisions made by consumers are based on purchase intention (Putri, 2018). Research conducted by Putri (2018), found that purchase intentions mediated the effect of perceived price on purchasing decisions.

H6: Purchase intention significantly mediates the perceived price on purchase decisions

The role of purchase intention in mediates perceived quality on purchase decision

Good product quality will affect the intention of consumers to buy products (Amilia, 2017). This means that perceived quality influences consumer purchase intentions (Wasis, 2013). High consumer purchase intentions will encourage consumers to buy a product (Adriansyah et al., 2013). Adriansyah et al. (2013), shows the results that buying intentions mediate the effect of perceived quality on purchasing decisions.

H7: Purchase intention significantly mediates perceived quality on the purchase decisions 


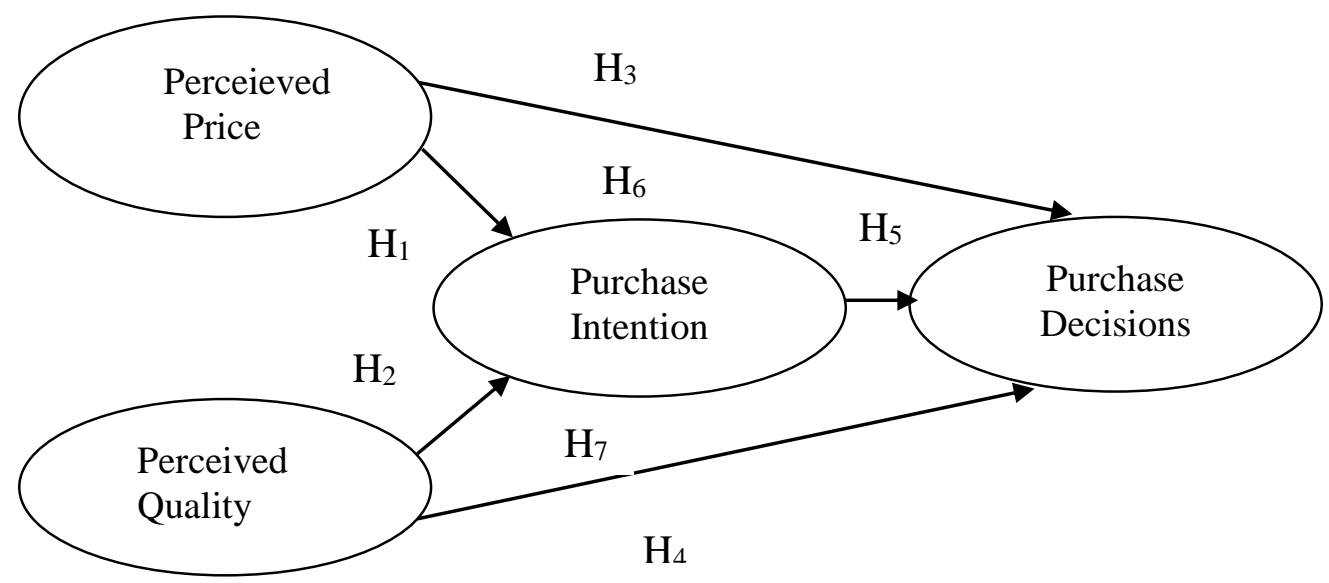

Figure 1. Conceptual framework

\section{Materials and Methods}

The scope of this study includes variables related to customer purchase intention and purchase decision where both of them are explained by perceived price and perceived quality (Gama et al., 2018). The population is consumers who have purchased a Xiaomi brand smartphone in Denpasar, using non-probability sampling with a purposive sampling method. The sample determined criteria are a consumer at age 17 years or more and have purchased Xiaomi smartphone at least than 3 months. The research was conducted in Denpasar by using a survey questionnaire with 16 indicators. The number of the sample depends on the number of indicators multiplied by 10 to 160 respondents. was Partial Least Square (PLS) analysis technique was used as explains by Ghozali (2011), that PLS does not assume that data must be with a certain scale of measurement.

\section{Results and Discussions}

Table 1

Respondent characteristic

\begin{tabular}{|c|c|c|c|c|}
\hline No & $\begin{array}{l}\text { Respondents } \\
\text { Characteristic }\end{array}$ & Classification & Total & Percentage \\
\hline \multirow[t]{3}{*}{1} & Gender & Male & 79 & $60.8 \%$ \\
\hline & & Female & 51 & $39.2 \%$ \\
\hline & Total & & & $100.0 \%$ \\
\hline \multirow[t]{6}{*}{2} & Age (year) & $17-24$ & 79 & $60.8 \%$ \\
\hline & & $25-34$ & 22 & $16.9 \%$ \\
\hline & & $35-44$ & 16 & $12.3 \%$ \\
\hline & & $45-54$ & 10 & $7.7 \%$ \\
\hline & & $>55$ & 3 & $2.3 \%$ \\
\hline & Total & & & $100.0 \%$ \\
\hline \multirow[t]{5}{*}{3} & Educational Level & Junior High School & 5 & $3.8 \%$ \\
\hline & & Senior High School & 87 & $66.9 \%$ \\
\hline & & Bachelor & 32 & $24.6 \%$ \\
\hline & & Other & 6 & $4.6 \%$ \\
\hline & Total & & & $100.0 \%$ \\
\hline \multirow[t]{3}{*}{4} & Occupation & Civil Servant & 10 & $7.7 \%$ \\
\hline & & Private Employee & 19 & $14.6 \%$ \\
\hline & & Entrepreneur & 20 & $15.4 \%$ \\
\hline
\end{tabular}

Satriawan, K. A., \& Setiawan, P. Y. (2020). The role of purchase intention in mediating the effect of perceived price and perceived quality on purchase decision. International Research Journal of Management,

IT and Social Sciences, 7(3), 38-49. https://doi.org/10.21744/irjmis.v7n3.887 


\begin{tabular}{clll}
\hline & Student & 75 & $57.7 \%$ \\
& Housewife & 6 & $4.6 \%$ \\
Total & & & $100.0 \%$ \\
\hline
\end{tabular}

Table 1 shows that male respondents dominate at 60.8 percent compared with female respondents at 39.2 percent. Based on age groups, respondents aged over 17 to 24 years have the highest percentage, which is 60.8 percent. Seen from the education level of the respondents, senior high schools student mostly purchases Xiaomi smartphones with a percentage of 66.9 percent. Based on the type of work, it was found that the group of students who bought about 57.7 percent. Based on these data can be used as information material for Xiaomi smartphone manufacturers to set a target market in the future.

Table 2

Validity test result

\begin{tabular}{lllll}
\hline \multirow{2}{*}{ No. } & Construct & Indicators & $\begin{array}{l}\text { Pearson } \\
\text { Correlation }\end{array}$ & Validity \\
\hline 1 & Perceived & Prices affect consumers in making decisions & 0,979 & Valid \\
& Price & Price match with the product quality & 0,958 & Valid \\
& & Price affordability & 0,977 & Valid \\
\multirow{2}{*}{2} & Perceived & Prices affect consumer purchasing power & 0,971 & Valid \\
& Quality & Performance & 0,969 & Valid \\
& & Durability & 0,961 & Valid \\
& & Conformance to specifications & 0,963 & Valid \\
3 & Purchase & Features & 0,977 & Valid \\
& Intention & Refrential value & 0,898 & Valid \\
& & Preferential value & 0,918 & Valid \\
\multirow{4}{*}{4} & Purchase & Explorative value & 0,963 & Valid \\
& Decisioning constancy & 0,363 & Valid \\
& & Buying consideration & 0,973 & Valid \\
& & Conformance of attributes with desires & 0,969 & Valid \\
& & Purchase decisions due to product quality & 0,973 & Valid \\
\hline
\end{tabular}

Based on Table 2 all question items show a standardized r-value higher than 0.3 at a significance level of 5 percent, so it can be explained that all construct indicators in this study are valid for research instruments.

Table 3

Reliability test result

\begin{tabular}{llll}
\hline No & Construct & Cronbach Alpha & Reliability \\
\hline 1 & Perceived price & 0,980 & Reliable \\
2 & Perceived quality & 0,977 & Reliable \\
3 & Purchase Intention & 0,940 & Reliable \\
4 & Purchase Decisions & 0,981 & Reliable \\
\hline
\end{tabular}

The Cronbach Alpha of all instruments in Table 3 is greater than 0.6. This shows that the measurement can give consistent results if it is taken again on the same subject. 
Table 4

Cross Loading Value

\begin{tabular}{llllll}
\hline Construct & Indicators & $\begin{array}{l}\text { Perceived } \\
\text { price }\end{array}$ & $\begin{array}{l}\text { Perceived } \\
\text { quality }\end{array}$ & $\begin{array}{l}\text { Purchase } \\
\text { Intention }\end{array}$ & $\begin{array}{l}\text { Purchase } \\
\text { Decisions }\end{array}$ \\
\hline Perceived & Prices affect consumers in making & $\mathbf{0 . 9 2 4}$ & 0.745 & 0.764 & 0.769 \\
price & decisions & & & 0.776 & 0.827 \\
& Price match with product quality & $\mathbf{0 . 9 5 5}$ & 0.784 & 0.778 \\
& Price affordability & $\mathbf{0 . 9 6 3}$ & 0.800 & 0.799 & 0.848 \\
& Prices affect the consumer purchasing & $\mathbf{0 . 9 3 9}$ & 0.818 & 0.791 & 0.835 \\
Perceived & power & & & \\
quality & Performance & 0.790 & $\mathbf{0 . 9 5 4}$ & 0.769 & 0.791 \\
& Durability & 0.801 & $\mathbf{0 . 9 0 7}$ & 0.713 & 0.782 \\
Purchase & Conformance to specifications & 0.780 & $\mathbf{0 . 9 5 2}$ & 0.764 & 0.793 \\
Intention & Features & 0.772 & $\mathbf{0 . 9 5 9}$ & 0.768 & 0.816 \\
& Transactional value & 0.631 & 0.656 & $\mathbf{0 . 8 7 7}$ & 0.679 \\
& Refrential value & 0.631 & 0.626 & $\mathbf{0 . 8 8 1}$ & 0.695 \\
Purchase & Preferential value & 0.780 & 0.744 & $\mathbf{0 . 9 1 4}$ & 0.827 \\
Decisions & Explorative value & 0.867 & 0.793 & $\mathbf{0 . 8 8 8}$ & 0.831 \\
& Buying constancy & 0.853 & 0.786 & 0.812 & $\mathbf{0 . 9 2 9}$ \\
& Buying consideration & 0.806 & 0.78 & 0.803 & $\mathbf{0 . 9 4 8}$ \\
& Conformance of attributes with desires & 0.801 & 0.832 & 0.815 & $\mathbf{0 . 9 5 1}$ \\
& Purchase decisions due to product & 0.829 & 0.798 & 0.827 & $\mathbf{0 . 9 6 3}$ \\
\hline
\end{tabular}

Based on Table 5, the correlation of constructs of the perceived price(X1) with its indicators is higher than the correlation with indicators of perceived quality (X2), purchase intention (Y1), and purchasing decisions (Y2). The correlation of the construct of perceived quality (X2) with the indicator is higher than the correlation with perceived indicators of the price (X1), purchase intention (Y1), and purchase decision (Y2). Furthermore, the correlation of constructs of purchase intention (Y1) with the indicator is higher than the correlation with indicators of the perceived price(X1), perceived quality (X2) and purchasing decisions (Y2). Correlation of the purchase decision construct (Y2) with its indicator is higher than the correlation with indicators of the perceived price(X1), perceived quality (X2) and purchase intention (Y1).

Discriminant validity by using square root average variance extracted and latent variable correlations

Table 5

Comparison of average variance extracted square root and latent variable correlations

\begin{tabular}{lllllll}
\hline & & AVE & \multicolumn{4}{c}{ Korelasi } \\
\cline { 5 - 7 } Construct & AVE & $\begin{array}{l}\text { root } \\
\text { value }\end{array}$ & $\begin{array}{l}\text { Perceived } \\
\text { price }\end{array}$ & $\begin{array}{l}\text { Perceived } \\
\text { quality }\end{array}$ & $\begin{array}{l}\text { Purchase } \\
\text { Intention }\end{array}$ & $\begin{array}{l}\text { Purchase } \\
\text { Decisions }\end{array}$ \\
\hline Perceived price & 0.894 & $\mathbf{0 . 9 4 6}$ & 1.000 & 0.833 & 0.828 & 0.868 \\
Perceived quality & 0.890 & $\mathbf{0 . 9 4 3}$ & 0.833 & 1.000 & 0.799 & 0.843 \\
Purchase Intention & 0.792 & $\mathbf{0 . 8 9 0}$ & 0.828 & 0.799 & 1.000 & 0.859 \\
Purchase Decisions & 0.898 & $\mathbf{0 . 9 4 8}$ & 0.868 & 0.843 & 0.859 & 1.000 \\
\hline
\end{tabular}

Table 6 concluded that the root value of the AVE construct of the perceived price (X1) is 0.946 , greater than the correlation between latent variables with other constructs other than perceived price (X1). The root value of the AVE construct of perceived quality (X2) is 0.943 , greater than the correlation between latent variables with other constructs other than perceived quality (X2). Furthermore, the root value of the AVE construct of purchase intention (Y1) is 0.890, greater than the correlation between latent variables with other constructs other than with purchase intention (Y1). The root value of the AVE construct of purchasing decisions (Y2) is 0.948 , greater than the correlation between latent variables with other constructs besides purchasing decisions (Y2).

Satriawan, K. A., \& Setiawan, P. Y. (2020). The role of purchase intention in mediating the effect of perceived price and perceived quality on purchase decision. International Research Journal of Management,

IT and Social Sciences, 7(3), 38-49. https://doi.org/10.21744/irjmis.v7n3.887 
Composite reliability

Table 6

Instrument reliability test result

\begin{tabular}{llll}
\hline Variable & Composite Reliability & Cronbach's Alpha & Reliability \\
\hline Perceived price (X1) & 0.971 & 0.960 & Reliable \\
Perceived quality (X2) & 0.970 & 0.959 & Reliable \\
Purchase Intention (Y1) & 0.939 & 0.913 & Reliable \\
Purchase Decisions (Y2) & 0.972 & 0.962 & Reliable \\
\hline
\end{tabular}

The construct reliability test is measured by two criteria, namely composite reliability and Cronbach's alpha of the block of indicator that measures the construct. The construct is declared reliable if the composite reliability and Cronbach's alpha values are above 0.70 .

Convergent validity

Convergent validity with reflexive indicators can be seen from the correlation between indicator scores and construct scores. Individual indicators are considered reliable if they have a correlation value above 0.70 . The results of the correlation between indicators and constructs can be seen in the following table:

Table 7

Outer loadings of price perceived construct

\begin{tabular}{|c|c|c|c|}
\hline Indicators & Outer Loadings & $t$ Statistics & $p$ Values \\
\hline $\begin{array}{l}\text { Xiaomi smartphone has an economical price compared to } \\
\text { other smartphones (X1.1) }\end{array}$ & 0.924 & 44.930 & 0.000 \\
\hline $\begin{array}{l}\text { Xiaomi smartphone prices offered line with the quality } \\
\text { obtained (X1.2) }\end{array}$ & 0.955 & 92.067 & 0.000 \\
\hline Xiaomi smartphone has an affordable price (X1.3) & 0.963 & 148.715 & 0.000 \\
\hline $\begin{array}{l}\text { The price of the Xiaomi smartphone is following my } \\
\text { purchasing power }(\mathrm{X} 1.4)\end{array}$ & 0.939 & 51.776 & 0.000 \\
\hline
\end{tabular}

Based on Table 7, the output results meet convergent validity because the loading factor is above 0.70 . It can be seen in the table above that the indicator "Xiaomi smartphone has an affordable price" (X.1.3) has the highest outer loadings value compared to other indicators namely 0.963 , it can be explained that these indicators can reflect the construct of price perceptions.

Table 8

Outer loadings of quality perceived construct

\begin{tabular}{llll}
\hline Indicators & Outer Loadings & t Statistics & $p$ Values \\
\hline Xiaomi smartphone performance is very good (X2.1) & 0.954 & 115.749 & 0.000 \\
Xiaomi smartphones have a long battery life (X2.2) & 0.907 & 30.379 & 0.000 \\
Xiaomi smartphone has specifications that fit my desire & 0.952 & 89.110 & 0.000 \\
(X2.3) & $\mathbf{0 . 9 5 9}$ & 112.911 & 0.000 \\
Xiaomi smartphone has complete features (X2.4) & & \\
\hline
\end{tabular}

Based on Table 8, the output results meet convergent validity because the loading factor is above 0.70 . It can be seen in the table above that the indicator "Xiaomi smartphone has complete features" (X2.4) has the highest outer loadings value compared to other indicators, namely 0.959 , it can be explained that these indicators can reflect the construct of quality perception. 
Table 9

Outer loadings of purchase intention construct

\begin{tabular}{llll}
\hline Indicators & Outer Loadings & t Statistics & $p$ Values \\
\hline $\begin{array}{l}\text { I will buy a Xiaomi smartphone shortly (Y1.1) } \\
\begin{array}{l}\text { I would recommend the Xiaomi smartphone to my family } \\
\text { and closest people (Y1.2) }\end{array}\end{array}$ & 0.877 & 34.197 & 0.000 \\
$\begin{array}{l}\text { Xiaomi smartphone will be my priority choice in the list of } \\
\text { smartphone purchases compared to other smartphone }\end{array}$ & 0.881 & 44.253 & 0.000 \\
$\begin{array}{l}\text { brands (Y1.3) } \\
\begin{array}{l}\text { I will look for information about the prices and } \\
\text { specifications of Xiaomi smartphones (Y1.4) }\end{array}\end{array}$ & $\mathbf{0 . 9 1 4}$ & 50.807 & 0.000 \\
\hline
\end{tabular}

Based on Table 9, the output results meet convergent validity because the loading factor is above 0.70 . It can be seen in the table above that the indicator "Xiaomi smartphone will be my priority choice in the list of smartphone purchases compared to other smartphone brands (Y1.3) has the highest outer loadings value compared to other indicators namely 0.914 , it can be explained that these indicators can reproduce the construct of purchase intentions. (Y1).

Table 10

Outer Loadings Konstruk Keputusan Pembelian

\begin{tabular}{llll}
\hline Indicators & Outer Loadings & t Statistics & $p$ Values \\
\hline $\begin{array}{l}\text { I bought a Xiaomi smartphone because the Xiaomi } \\
\text { smartphone has an elegant product design (Y2.1) }\end{array}$ & 0.929 & 39.199 & 0.000 \\
$\begin{array}{l}\text { I bought a Xiaomi smartphone because of price and quality } \\
\text { considerations (Y2.2) }\end{array}$ & 0.948 & 94.219 & 0.000 \\
$\begin{array}{l}\text { I bought a Xiaomi smartphone because the features and } \\
\text { design fit my preference (Y2.3) }\end{array}$ & 0.951 & 103.313 & 0.000 \\
$\begin{array}{l}\text { I bought a Xiaomi smartphone because the quality of the } \\
\text { Xiaomi smartphone is guaranteed (Y2.4) }\end{array}$ & $\mathbf{0 . 9 6 3}$ & 155.406 & 0.000 \\
\hline
\end{tabular}

Based on Table 10, the output results meet convergent validity because the loading factor is above 0.70 . It can be seen in the table above that the indicator "I bought a Xiaomi smartphone because the quality of a Xiaomi smartphone is guaranteed" (Y2.4) has the highest outer loadings value compared to other indicators namely 0.963 , so it can be explained that the indicator can reflect the construct of a purchasing decision (Y2).

\section{Evaluate structural models or inner models}

Based on Table 11, the model of the effect of perceived price and perceived quality on purchase intention gives an Rsquare value of 0.725 which can be interpreted that the variability of the purchase intention construct can be explained by the construct of perceived price and perceived quality of 72.5 percent, while 27.5 percent, explained by other constructs outside of the study.

Furthermore, the model of the effect of perceived price and quality perception, and purchase intention on purchasing decisions gives an R-square value of 0.835 which can be interpreted that the variability of the purchase decision construct can be explained by the construct of price perception, quality perception, and purchase intention of 83.5 percent, while 16.5 percent is explained by other constructs outside of the study.

Table 11

R-square

\begin{tabular}{ll}
\hline Constructs & R--square \\
\hline Purchase Intention (Y1) & 0.725 \\
Purchase Decision (Y2) & 0.835 \\
\hline
\end{tabular}

Satriawan, K. A., \& Setiawan, P. Y. (2020). The role of purchase intention in mediating the effect of perceived price and perceived quality on purchase decision. International Research Journal of Management, IT and Social Sciences, 7(3), 38-49. https://doi.org/10.21744/irjmis.v7n3.887 
To assess how well the observational values generated by the model and also the estimated parameters, it is necessary to calculate the $\mathrm{Q}$-square as follows:

Q2 $\quad \begin{aligned} & =1-\left(1-\left(\mathrm{R}_{1}\right)^{2}\right)\left(1-\left(\mathrm{R}_{2}\right)^{2}\right) \\ & =1-(1-0,725)(1-0,835) \\ & =0,955\end{aligned}$

The quantity Q2 has a value with a range of $0<1$, where the closer to 1 means the better the model. Therefore, the results of the calculation obtained the $\mathrm{Q} 2$ value of 0.955 , so it can be concluded that the model has a good predictive relevance $(\mathrm{Q} 2=0.955>0)$.

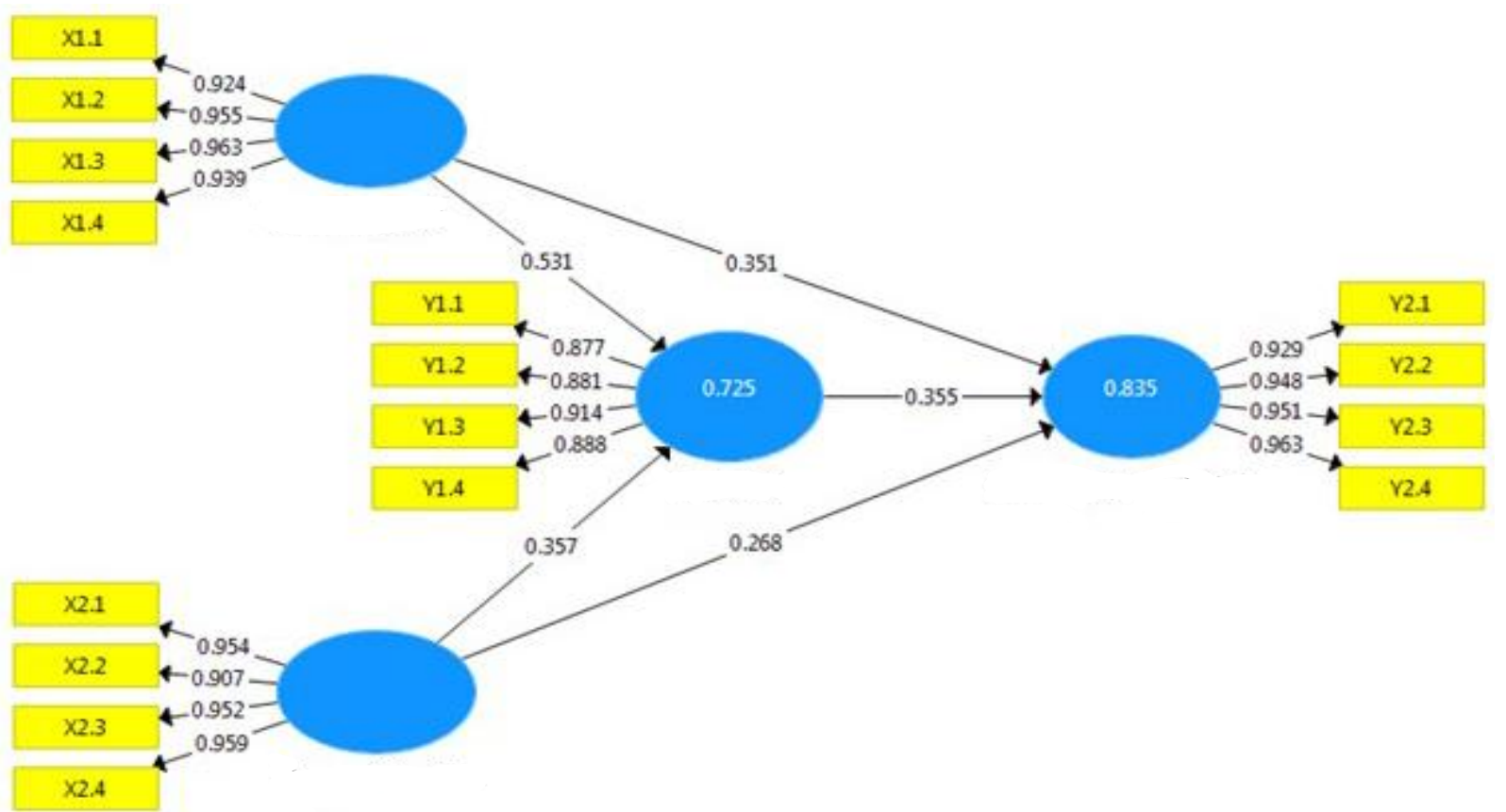

Figure 2. Partial Least Square result

H1: which stated that price perceived has a positive and significant effect on purchase intention is accepted with a correlation coefficient of 4.022 and a calculated $t$ value $>t$ table 1.96 at a significant level of 5 percent.

H2: which stated that perceived quality has a positive and significant effect on purchase intention is accepted with a correlation coefficient of 2.653 and a calculated $t$ value $>t$ table 1.96 at a significant level of 5 percent.

H3: which stated that price perceived has a positive and significant effect on purchasing decisions is accepted with a correlation coefficient of 3.264 and $t$ count> t table 1.96 at a significant level of 5 percent.

H4: which stated that the perceived quality has a positive and significant effect on purchasing decisions is accepted with a correlation coefficient of 2.944 and the $t$ value $>t$ table 1.96 at a significant level of 5 percent.

H5: which stated that purchase intention has a positive and significant effect on purchase decisions is accepted with a correlation coefficient of 3.573 and a calculated t value> t table 1.96 at a significant level of 5 percent. 
Table 12

Indirect effects

\begin{tabular}{lcrc}
\hline Variables & Correlation & t Statistics & \multicolumn{1}{l}{$\begin{array}{l}\text { Values } \\
\text { Coef. }\end{array}$} \\
\hline Perceived price (X1) to purchase decision (Y2) & 0.188 & 2.871 & 0.004 \\
Perceived quality (X2) to purchase decision (Y2) & 0.127 & 2.020 & 0.044 \\
\hline
\end{tabular}

The mediating role of purchase intentions on the effect of perceived price on purchasing decisions

The results of direct influence show that the coefficient value of the perceived price of purchasing decisions is 0.351 with $t$ statistics value of 3.264 and a p-value of 0.001 . Testing of purchase intention as a mediating variable is done by calculating the value of the Variance Accounted For (VAF).

Purchase intention as a mediating variable has a VAF value of $0,349(34.9 \%)$. So it can be concluded that the purchase intention has a partial mediating role in the relationship between the effect of price perception on purchasing decisions, which means that price perceptions can influence purchase decisions directly or indirectly through purchase intentions. So the hypothesis stating that purchase intention acts as a mediator of the relationship between price perception of Xiaomi smartphone purchasing decisions can be accepted.

The mediating role of purchase intentions on the effect of perceived quality on purchasing decisions

The direct effect test results by including mediation in Table 12 shows that the coefficient of perceived quality of the purchase decision is 0.268 with a t-statistic of 2.944 and a p-value of 0.003 , so the hypothesis is accepted. The testing of purchase intention as a mediating variable is done by calculating the value of VAF in Table 5.19.

Based on the data presented in Table 12, purchase intention as a mediating variable has a VAF of $0.322(32.2 \%)$. So it can be concluded that purchase intention has a partial mediating role in the relationship between perceived quality of purchasing decisions, which means perceived quality can influence purchasing decisions directly or indirectly through purchase intentions. So the hypothesis stating that purchase intention acts as a mediator of the relationship between perceived quality of purchasing decisions can be accepted.

\section{Conclusion}

Based on the results of the discussion it can be concluded that perceived price and perceived quality positively and significantly affect purchase intentions and purchase decisions of Xiaomi smartphones. Purchase intention also plays a significant role in mediated the perceived price and perceived quality towards the Xiaomi smartphone purchase decision. Xiaomi smartphone manufacturers should pay attention to the suitability between the price offered and the quality obtained to show that Xiaomi smartphone products worth the price. Xiaomi also needs to increase battery life and capacity as it one of the factors that consumers remain satisfied with, last Xiaomi smartphone manufacturers should be more aggressively carrying out through social media such as, as well as conventional media such as television and newspapers to wider coverage of consumers.

\section{Conflict of interest statement}

The authors declared that they have no competing interests.

\section{Statement of authorship}

The authors have a responsibility for the conception and design of the study. The authors have approved the final article.

\section{Acknowledgments}

We are grateful to two anonymous reviewers for their valuable comments on the earlier version of this paper.

Satriawan, K. A., \& Setiawan, P. Y. (2020). The role of purchase intention in mediating the effect of perceived price and perceived quality on purchase decision. International Research Journal of Management, 


\section{References}

Adriansyah, M. A., Aryanto, R., Toindo, H., \& Agusthina, S. (2013). Peran Minat Pembelian Konsumen sebagai Mediasi Kualitas Produkterhadap Keputusan Pembelian pada Perusahaan Kue. Binus Business Review, 4(1), 349359. https://doi.org/10.21512/bbr.v4i1.1125

Akhter, S. H. (2003). Digital divide and purchase intention: Why demographic psychology matters. Journal of Economic Psychology, 24(3), 321-327. https://doi.org/10.1016/S0167-4870(02)00171-X

Alfred, O. (2013). Influences of price and quality on consumer purchase of mobile phone in the Kumasi Metropolis in Ghana a comparative study. European Journal of Business and Management, 5(1), 179-198.

Amilia, S. (2017). Pengaruh Citra Merek, Harga, dan Kualitas Produk terhadap Keputusan Pembelian Handphone Merek Xiaomi di Kota Langsa. Jurnal Manajemen dan Keuangan, 6(1), 660-669.

Anwar. (2017). Pengaruh Persepsi Harga dan Kualitas Produk Terhadap Keputusan Pembelian Konsumen Smartphone Oppo Pada Toko Handphone Mandiri Medan. Jurnal Ilmiah Politeknik Mandiri Bina Prestasi. 6(2).

Babin, B. J., Hardesty, D. M., \& Suter, T. A. (2003). Color and shopping intentions: The intervening effect of price fairness and perceived affect. Journal of business research, 56(7), 541-551. https://doi.org/10.1016/S01482963(01)00246-6

Balakrishnan, B. K., Dahnil, M. I., \& Yi, W. J. (2014). The impact of social media marketing medium toward purchase intention and brand loyalty among generation Y. Procedia-Social and Behavioral Sciences, 148, $177-185$. https://doi.org/10.1016/j.sbspro.2014.07.032

Bian, Q., \& Forsythe, S. (2012). Purchase intention for luxury brands: A cross cultural comparison. Journal of Business Research, 65(10), 1443-1451. https://doi.org/10.1016/j.jbusres.2011.10.010

Brata, B. H., Husani, S., \& Ali, H. (2017). The influence of quality products, price, promotion, and location to product purchase decision on Nitchi at PT. Jaya Swarasa Agung in Central Jakarta. Saudi Journal of Business and Management Studies, 2(4), 357-374. https://doi.org/10.21276/sjbms

Chao R.F. (2016). "The impact of brand image and discounted price on purchase intention in outlet mall: Consumer attitude as mediator." source: The Journal of Global Business Management 12(2), 119-128.

Gama, A. W. S., Rustiarini, N. W., \& Anggraini, N. P. N. (2018). Imaging and Purchasing Decision in Traditional Art Market. International Research Journal of Management, IT and Social Sciences, 5(2), 175-185.

Ghozali, I. (2011). Aplikasi multivariate dengan program IBM SPSS 19. Semarang: Badan Penerbit Universitas Diponegoro.

González, M. E. A., Comesaña, L. R., \& Brea, J. A. F. (2007). Assessing tourist behavioral intentions through perceived service quality and customer satisfaction. Journal of business research, 60(2), 153-160. https://doi.org/10.1016/j.jbusres.2006.10.014

Hastuti H.B.N., Rommy N. S. A. M., Nur N.Y.R.A. (2018). Effect Of Brand Image And Price Perception On Purchase Decision. Journal of Business and Management. 20(8), 76-81

Hendra, L. (2017). Impact of Brand Image, Product Quality and Self-Efficacy on Purchase Decisions on Private Label Rights Products. An Empirical Study. Expert Journal of Business and Management, 5(2).

Hidayah, R. T. (2016). Pengaruh Brand Trust Terhadap Niat Konsumen Untuk Melakukan Pembelian Produk Elektronik Pada Situs Jual Beli Lazada. UNEJ e-Proceeding, 122-132.

Hoseinian, B. B., \& Asadollahi, A. (2017). Review the behavioral characteristics of sellers on customer orientation, communication and customer satisfaction (Case Study: City Carpet). Management, 4(1), 42-57.

Hustic, I., \& Gregurec, I. (2015). The influence of price on customer's purchase decision. In Central European Conference on Information and Intelligent Systems (p. 27). Faculty of Organization and Informatics Varazdin.

Jang, S. S., \& Namkung, Y. (2009). Perceived quality, emotions, and behavioral intentions: Application of an extended Mehrabian-Russell model to restaurants. Journal of Business Research, 62(4), 451-460. https://doi.org/10.1016/j.jbusres.2008.01.038

Kayacan, M. (2017). Effect of Price and Brand on Purchase Decision-An Application on Turkish Smart Phone Consumers.

Lee, K. H., \& Shin, D. (2010). Consumers' responses to CSR activities: The linkage between increased awareness and purchase intention. Public Relations Review, 36(2), 193-195. https://doi.org/10.1016/j.pubrev.2009.10.014

Li, C. P. (2017). Effects of Brand Image, Perceived Price, Perceived Quality, and Perceived Value on the Purchase Intention towards Sports and Tourism Products of the 2016 Taichung International Travel Fair. The Journal of International Management Studies, 12(2), 11.

Lomboan, L. K. (2017). Analysis the influence of perceived quality, perceived price and perceived value on consumer purchase intention in traditional fabrics (Case Study Kaeng Manado). Jurnal Berkala Ilmiah Efisiensi, 17(01). 
Mahajaya Utama, K. T., \& Sudiksa, I. B. (2017). Peran Respon Emosi Memediasi Pengaruh Atribut Produk Terhadap Brand Switching. E-Jurnal Manajemen Universitas Udayana, 6(5).

O'Cass, A. (2000). An assessment of consumers product, purchase decision, advertising and consumption involvement in fashion clothing. Journal of Economic Psychology, 21(5), 545-576. https://doi.org/10.1016/S01674870(00)00018-0

Octaviona, N. (2016). Pengaruh Citra Merek Dan Persepsi Harga Terhadap Keputusan Pembelian Gadget Di Toko Suryaphone Samarinda. journal Psikologi, 4, 397-407.

Putra, E. W., Kumadji, S., \& Yulianto, E. (2016). Pengaruh Diskon Terhadap Minat Beli Serta Dampaknya Pada Keputusan Pembelian (Study Pada Konsumen Yang Membeli Produk Diskon Di Matahari Department Store Pasar Besar Malang). Jurnal Administrasi Bisnis, 38(2), 184-193.

Putri Rinda Desy Elisa. (2018). Pengaruh Kualitas Produk dan Harga Terhadap Keputusan Pembelian Melalui Minat Beli (Studi Pada Konsumen Wardah Cosmetics Di Indonesia. Program Studi Manajemen Fakultas Ekonomi Universitas Sanata Dharma Yogyakarta

Rawung, D. R., Oroh, S. G., \& Sumarauw, J. S. (2015). Analisis Kualitas produk, merek dan harga terhadap keputusan pembelian sepeda motor Suzuki Pada PT. Sinar Galesong Pratama Manado. Jurnal EMBA: Jurnal Riset Ekonomi, Manajemen, Bisnis dan Akuntansi, 3(3). https://doi.org/10.35794/emba.v3i3.10413

Safitri, I. (2018). The Influence of Product Price on Consumers' Purchasing Decisions. Review of Integrative Business and Economics Research, 7, 328-337.

Saleem, A., Ghafar, A., Ibrahim, M., Yousuf, M., \& Ahmed, N. (2015). Product perceived quality and purchase intention with consumer satisfaction. Global journal of management and business research.

Septiana. (2018). Pengaruh Persepsi Harga, Kepercayaan, Dan Persepsi Nilai Terhadap Minat Beli Di E-Commerce. TESIS. Program Pasca Sarjana Fakultas Ekonomi Program Studi Magister Manajemen Universitas Islam Indonesia

Septifani, R., Achmadi, F., \& Santoso, I. (2014). Pengaruh green marketing, pengetahuan dan minat membeli terhadap keputusan pembelian. Jurnal Manajemen Teknologi, 13(2), 201-218.

Stock, J. R., \& Zinszer, P. H. (1987). The industrial purchase decision for professional services. Journal of Business Research, 15(1), 1-16. https://doi.org/10.1016/0148-2963(87)90014-2

Tansil, M. J., \& Tielung, M. V. (2014). The Effect of Perceived Price and Perceived Quality on Purchase Intention at Shmily Cupcakes Store Manado. Jurnal EMBA: Jurnal Riset Ekonomi, Manajemen, Bisnis dan Akuntansi, 2(3). https://doi.org/10.35794/emba.v2i3.5808

Wang, Y. H., \& Chen, L. Y. (2016). An empirical study of the effect of perceived price on purchase intention evidence from low-cost carriers. International Journal of Business and Social Science, 7(4), 97-107.

Wasis, K. (2013). Pengaruh Persepsi Kualitas dan Harga terhadap Minat Beli Tablet Samsung Galaxy Tab. Jurnal Ilmu Manajemen (JIM), 1(3).

Waspodo, B. B. E. (2010). Studi Tentang Keputusan Pembelian Honda Vario Di Kota Semarang. Jurnal Sains Pemasaran Indonesia (Indonesian Journal of Marketing Science), 9(1), 45-58. https://doi.org/10.14710/jspi.v9i1.45-58

Wichman, C. J. (2014). Perceived price in residential water demand: Evidence from a natural experiment. Journal of Economic Behavior \& Organization, 107, 308-323. https://doi.org/10.1016/j.jebo.2014.02.017

Widyastuti, S., \& Said, M. (2017). Consumer consideration in purchase decision of SPECS sports shoes product through brand image, product design and price perception. International Journal of Supply Chain Management, 6(4), 199-207.

Zhang, T., \& Zhang, D. (2007). Agent-based simulation of consumer purchase decision-making and the decoy effect. Journal of business research, 60(8), 912-922. https://doi.org/10.1016/j.jbusres.2007.02.006

Satriawan, K. A., \& Setiawan, P. Y. (2020). The role of purchase intention in mediating the effect of perceived price and perceived quality on purchase decision. International Research Journal of Management,

IT and Social Sciences, 7(3), 38-49. https://doi.org/10.21744/irjmis.v7n3.887 